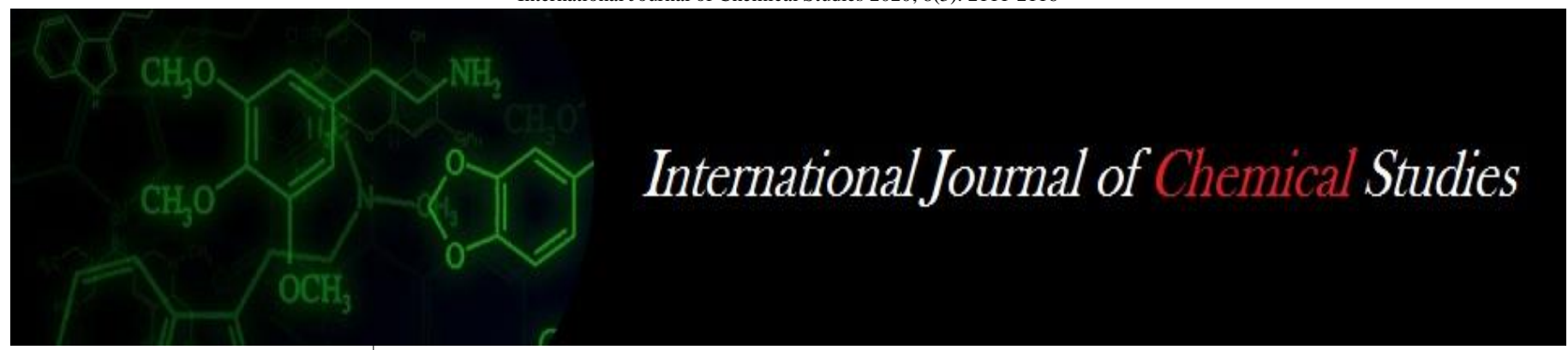

P-ISSN: 2349-8528

E-ISSN: 2321-4902

www.chemijournal.com

IJCS 2020; 8(3): 2111-2116

(C) 2020 IJCS

Received: 05-03-2020

Accepted: 08-04-2020

\section{Mousumi Gogoi}

Department of Food Science and

Nutrition, Assam Agricultural

University, Jorhat, Assam, India

\section{Dr. Mridula Saikia Barooah}

Department of Food Science and

Nutrition, Assam Agricultural

University, Jorhat, Assam, India

Dr. Premila L Bordoloi

Department of Food Science and

Nutrition, Assam Agricultural

University, Jorhat, Assam, India

Dr. Pritom Kr Borthakur

Department of Horticulture,

Assam Agricultural University,

Jorhat, Assam, India

\section{Borsha Neog}

Department of Agricultural

Statistics, Assam Agricultural

University, Jorhat, Assam, India

Corresponding Author:

Mousumi Gogoi

Department of Food Science and

Nutrition, Assam Agricultural

University, Jorhat, Assam, India

\section{Study on storage stability of gluten free biscuit prepared by using rice flour, soya flour and buckwheat flour}

\author{
Mousumi Gogoi, Dr. Mridula Saikia Barooah, Dr. Premila L Bordoloi, \\ Dr. Pritom Kr Borthakur and Borsha Neog
}

DOI: https://doi.org/10.22271/chemi.2020.v8.i3ad.9521

\begin{abstract}
Gluten free biscuits were prepared by using Non-waxy rice flour(NW) and Waxy rice flour(W), buckwheat flour(BF), soya flour(SF) at a ratio of 40:30:20:10 (NW:W:BF:SF) respectively. Shelf life study was done by storing biscuit (T) for 4 weeks in different packaging materials and sensory evaluation was done in 7 days interval. Overall acceptability of biscuit was decreased slightly from 0 days to 28 days in all three types of packaging, but were within an acceptable range. Biscuits stored in different packaging materials does have significant affect on changes in moisture content, free fatty acid and peroxide value during storage. Highest moisture content was in PP followed by HDPE and then airtight container. Free fatty acid was low inbiscuits kept in airtight container. There was significant increase in peroxide value across storage but were below FSSAI limitation $(10 \mathrm{mEq} / \mathrm{kg}$ oil) and lowest value was found in biscuits kept in airtight container.
\end{abstract}

Keywords: Biscuit, buckwheat, gluten free, rice flour, soya flour, storage

\section{Introduction}

Among baked, ready-to-eat snacks food item, biscuit is mostly preferred snacks which is consumed by all age groups of population. Moreover, gluten free biscuits are at high demand nowadays also suitable for celiac patient (Hopman et al., 2006) ${ }^{[7]}$. These are manufactured by large organized bakery as well as at small scale bakery unit, wherein storage of biscuit or shelf stability is very important. Generally, this is the product with good shelf life and that may be the reason for high consumer demands (Masoodi et al., 2012) ${ }^{[10]}$. This is the product with good shelf life and one of the most liked bakery products by the urban as well as rural consumers. Biscuit industry in India is pegged at 3,000 crores of which the unorganized sector accounts as much as $35 \%$. India is one of the largest biscuit producers in the world. This snack item is prepared of wheat flour as a base ingredient but in this study rice flour, soya flour and buckwheat flour are used instead of wheat flour. Nowadays, bakery units made many advances in this sector by using additives and packaging materials to increase shelf life of products. The acceptability of a biscuit or any snack items are based on the deterioration level and rancidity is the main cause for deterioration. This in turn causes foul smell, loss of nutritional quality, undesirable texture, colour and also threat to food safety. Another important factor is packaging. It forms an integral part of manufacturing process for filling the gap between producer and consumer. Apart from this, it also facilitates for storing of food items.

Therefore, considering above points, present investigation was planned to prepare a gluten free biscuit by using rice flours, soya flour and buckwheat flour and conduct a study or storage stability in different packaging materials for a fixed period.

\section{Materials and Methods}

\subsection{Procurement of raw materials}

Rice, soyabean and buckwheat were selected for the present study due to their gluten free properties. For carrying out the present study required samples like two varieties of rice namely, $\mathrm{V}_{1}$ (Bahadur) was a non waxy grain collected from local market of Jorhat town and $\mathrm{V}_{2}$ (Aghuni bora) was a waxy grain collected from Regional Agricultural Research Station 
(RARS), Titabor, Jorhat. Soyaflour was procured from local market, buckwheat was collected from Gosaigaon, Krishi Vigyan Kendra (KVK), Kokrajhar. Other ingredients required for preparation of biscuits were bought from local market.

\subsection{Processing of raw materials}

All the raw materials were processed to make them ready for manufacturing the product. Ingredients i.e. two varieties of rice and buckwheat were processed into flour in order to use them as base ingredient for development of rice based biscuits.

\subsubsection{Processing of rice varieties into flour}

Rice were cleaned and soaked for 2 hours. After that water was drained off and soaked rice were dried for 1 hour in the sunlight. Rice flour was obtained by grinding it to fine powder in an electric grinder and sieved through 72 size sieve.

\subsubsection{Processing of buckwheat into flour}

Buckwheat was cleaned and washed properly and dried in full sunlight for 2 days. After drying the grains were subjected to milling and winnowing was done for separating the kernels from husk. Buckwheat flour was obtained by grinding it to a fine powder.

\subsection{Preparation of gluten free biscuit}

The biscuit was prepared from flour mix prepared by mixing two varieties of rice flours Non-waxy(NW) and Waxy rice flour (W), buckwheat flour(BF), soya flour(SF) at a ratio of 40:30:20:10 (NW:W:BF:SF) respectively which is named as "T" and were used to prepare 100gm flour mix for biscuit. The biscuits were prepared by traditional method of mixing. Creaming was done by mixing margarine, powdered sugar, egg and vanilla essence. Flours were added with baking powder and salt into the cream and made into a dough. The dough was rolled out into a sheet using a rolling pin and cut into desired shape using a cutter and subjected to baking in an oven at $180^{\circ} \mathrm{c}$ for 15 minutes. List of ingredients were given in table 1.

Table 1: List of ingredients used in the preparation of biscuits

\begin{tabular}{|c|c|c|}
\hline Sl. No. & Ingredients & T \\
\hline 1 & Non waxy rice flour $(\mathrm{g})$ & 40 \\
\hline 2 & Waxy rice flour $(\mathrm{g})$ & 30 \\
\hline 3 & Buckwheat flour $(\mathrm{g})$ & 20 \\
\hline 4 & Soya flour $(\mathrm{g})$ & 10 \\
\hline 5 & Egg $(\mathrm{g})$ & 10 \\
\hline 6 & Sugar powder $(\mathrm{g})$ & 40 \\
\hline 7 & Margarine $(\mathrm{g})$ & 50 \\
\hline 8 & Baking powder $(\mathrm{g})$ & 2 \\
\hline 9 & Vanilla essence $(\mathrm{ml})$ & 2 \\
\hline 10 & Salt $(\mathrm{g})$ & 1 \\
\hline
\end{tabular}

\subsection{Study on storage stability of gluten free biscuit}

It is very important to see the keeping quality of biscuits in household storage practices and hence, shelf life studies were carried out by storing the biscuits in airtight containers, HDPE and also in PP pouches. Sensory evaluation, moisture content, free fatty acid and peroxide value of gluten free biscuits were estimated at an interval of $0,7,14,21,28$ days.

\subsubsection{Specification of packaging materials}

1. Airtight container: Packaging coming into contact with developed biscuit (primary packaging). Brand name:
Milton. Plastic type- Polyethylene terephthalate (PET). Capacity- 1000 ml. Number - 1 unit. Art no.- PET 29. (Figure 1)

2. Plastic pouch: Packaging coming into contact with developed biscuit (primary packaging). Brand name: IndiaMart. Plastic type- High Density Polyethylene (HDPE). Size = 10" x 6". Gauge $=250$ gauge. (Figure 2)

3. Plastic pouch: Packaging coming into contact with developed biscuit (primary packaging). Brand name: India Mart. Plastic type- Polypropylene (PP). Size= 8 "x6". Gauge $=150$ gauge. (Figure 3)

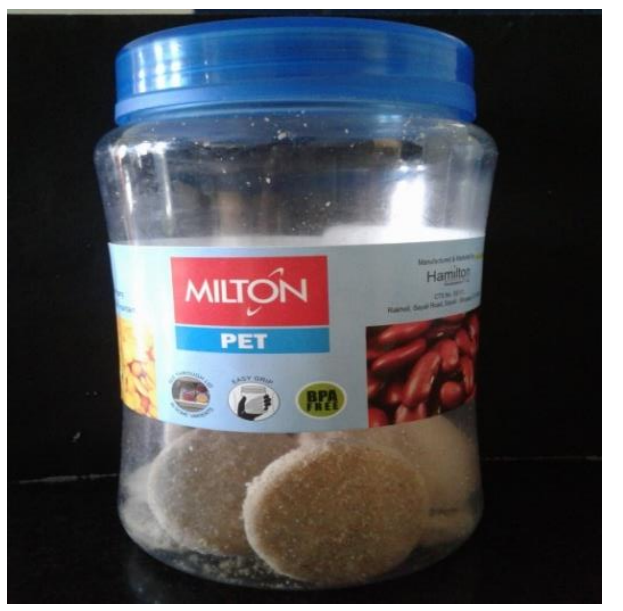

Fig 1: Gluten free biscuit (T) kept in Airtight container

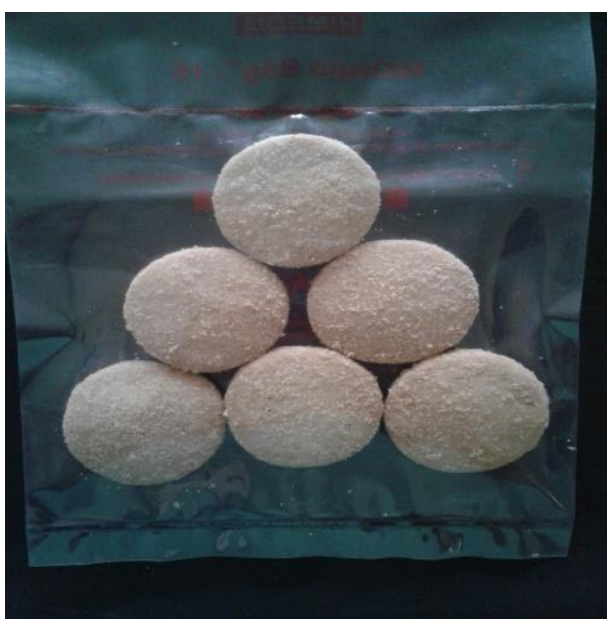

Fig 2: Gluten free biscuit (T) kept in HDPE

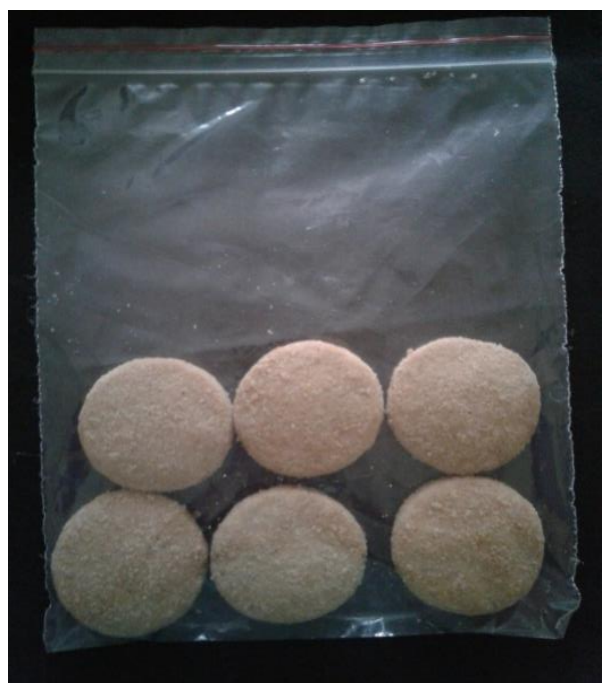

Fig 3: Gluten free biscuit (T) kept in PP 
Sensory evaluation was done in the sensory laboratory of department of Food Science and Nutrition, college of community science, AAU along with Department of horticulture, college of agriculture, AAU. Sensory attributes for developed formulations were analyzed across storage upto 28 days. Judges were asked to score products for attributes i.e. Colour, texture, aroma, taste, appearance and overall acceptability using a scorecard of nine point hedonic rating scale.

The moisture content of the freshly harvested sample was determined by oven drying method (AOAC, 2010).

Determination of free fatty acid is calculated by a formula (Cox, H.E and Pearson, D. 1962):

Calculation: Acid value $(\mathrm{mg} \mathrm{KOH} / \mathrm{g})=\frac{\text { Titrate value } \mathrm{x} \text { Normality of KOH } \times 56.1}{\text { Weight of the sample }(g)}$

Peroxide value of the sample was determined by following the A.O.A.C (1975) method.

Calculation for peroxide value is

Peroxide value (mili equivalent $/ \mathrm{Kg}$ sample) $=[1000(\mathrm{~V}-$ $\mathrm{X}) \mathrm{N}] / \mathrm{W}$

\section{Where}

$\mathrm{V}=$ Volume of sodium thiosulphate solution used for sample

$\mathrm{X}=$ Volume of sodium thiosulphate solution used for blank

$\mathrm{N}=$ Normality of sodium thiosulphate solution

$\mathrm{W}=$ Weight of the sample

The results may be expressed in terms of mili equivalent per $1000 \mathrm{~g}$ of oil or in milli moles per $1000 \mathrm{~g}$ of oil.

\subsection{Statistical analysis}

The data analysis was done in software IBM SPSS version 20. The data recorded for impact of period and packaging material in terms of sensory evaluation, moisture content, free fatty acid and peroxide value during storage was subjected to analysis of variance (ANOVA) for $2^{2}$-factorial completely randomized design suggested by Gomes and Gomes (1984). The standard error of differences $(\mathrm{S}$.Ed \pm ) was calculated by using the following expression:

$$
\text { S.Ed } \pm=\sqrt{\frac{\text { Error } \text { mean square } \times 2}{\text { No. of replication }}}
$$

Methods applied for these are given below

Mean: It is sum of all the observations $\left(\Sigma \mathrm{X}_{\mathrm{i}}\right)$ divided by the number of observations $(\mathrm{N})$. The formula of calculating means $(\overline{\mathrm{X}})$ is as follows:

$$
\overline{\mathrm{X}}=\frac{\sum \mathrm{X}_{\mathrm{i}}}{\mathrm{N}}
$$

Standard deviation: Standard deviation is the positive square root of the arithmetic mean of the squares of deviations of the given values from arithmetic mean. If the standard deviations of a sample were smaller than the population, then it is measured by using the following formula:

Standard deviation $(\sigma)=\frac{\sum(\mathrm{Xi}-\mathrm{X})^{2}}{\mathrm{~N}}$

\section{Where}

$\mathrm{Xi}=$ Observations

$\mathrm{X}=$ Arithmetic mean

$\mathrm{N}=$ Number of observations

\section{Results and Discussions}

Sensory evaluation across storage: Sensory evaluation was done in sensory laboratory of Department of Food Science and Nutrition. Prepared biscuits were evaluated thrice for their sensory qualities by a panel of 10 judges selected at random from Department of Food Science and Nutrition, College of Community Science, AAU. Sensory attributes for prepared formulation was analyzed across storage upto 4 weeks. Judges were asked to score the products for each and every quality attributes i.e. colour, appearance, taste, texture, aroma and overall acceptability using a score card of 9 point hedonic rating scale. The scores are presented in Table 2 . In table 3 the scores depicted for organoleptic characters of biscuits stored in different packaging materials for 4 weeks does have significant affect on overall acceptability of biscuit as days increase in storage period. The overall acceptability scores of developed and accepted biscuit decreased as days increased although it decreased gradually throughout the storage period, but it was acceptable till 28 days and may be taken beyond it. There was significant decrease in overall acceptability scores across storage. Mean overall acceptability of biscuit in airtight container was 8.36, in HDPE it was 8.23 and in PP it was 8.12 . Highest score was obtained by biscuit kept in airtight container. From factor period (1817.77***) also it can be seen that overall acceptability decreases as days increased. On 28 days score was lowest being 7.28. Analysis performed for packaging materials indicates that biscuit kept in airtight container obtained highest score in terms of overall acceptability. Surekha et al. (2013) ${ }^{[17]}$ reported that scores gradually decreased throughout the period from 30 days onwards. Storage studies also indicate a significant decrease in mean colour score of the biscuits. There was darkening in colour during storage that attained lower colour scores in all the formulations. Pasha et al. (2002) ${ }^{[13]}$ also observed the same pattern of decrease in colour during 60 days storage of cookies. Taste of developed biscuit also decreased as storage period increased, decrease in taste during storage may occur due to rancidity of fat to some extent. Berwal et al. in $2013^{\text {[3'] }}$ also found a decrease in mean score for taste after 60 days storage in biscuits prepared from composite flour.

Table 2: Mean acceptability scores of quality attributes of accepted prepared gluten free biscuit (T) across storage of 28 days

\begin{tabular}{|c|c|c|c|c|c|c|c|}
\hline \multirow{2}{*}{ Product } & \multirow{2}{*}{ Storage days } & \multicolumn{6}{|c|}{ Quality attributes } \\
\cline { 3 - 8 } & & Colour & Taste & Aroma & Texture & Appearance & Overall acceptability \\
\hline & 0 day & $8.3 \pm 0.2$ & $8.8 \pm 0.1$ & $8.7 \pm 0.2$ & $8.6 \pm 0.2$ & $8.7 \pm 0.2$ & $9.0 \pm 0$ \\
\hline $\mathrm{T}$ & 7 days & $8.3 \pm 0.6$ & $8.7 \pm 0.18$ & $8.5 \pm 0.7$ & $8.4 \pm 0.05$ & $8.5 \pm 0.8$ & $8.8 \pm 0.06$ \\
\hline & 14 days & $8.2 \pm 0.3$ & $8.5 \pm 0.6$ & $8.4 \pm 0.4$ & $8.3 \pm 0.03$ & $8.3 \pm 0.04$ & $8.6 \pm 0.5$ \\
\hline & 21 days & $8 \pm 0.4$ & $7.7 \pm 0.8$ & $7.8 \pm 0.2$ & $7.7 \pm 0.4$ & $7.9 \pm 0.9$ & $8 \pm 0.3$ \\
\hline & 28 days & $7.8 \pm 0.6$ & $6.9 \pm 0.2$ & $7 \pm 0.8$ & $7.2 \pm 0.01$ & $7.3 \pm 0.7$ & $7.5 \pm 0.2$ \\
\hline
\end{tabular}


Table 3: Impact of period and packaging materials in terms of overall acceptability of sensory evaluation for Treatment $\mathrm{T}$ kept across storage

\begin{tabular}{|c|c|c|c|c|c|c|c|c|}
\hline \multirow{2}{*}{ Parameter } & \multirow{2}{*}{$\begin{array}{l}\text { Period of } \\
\text { evaluation } \\
\text { (Days) }\end{array}$} & \multicolumn{3}{|c|}{ Packaging materials (mean \pm SD) } & \multirow[t]{2}{*}{$\begin{array}{c}\text { Period of evaluation } \\
\text { (Days) mean } \pm \text { SD }\end{array}$} & \multirow[t]{2}{*}{ F value } & \multirow{2}{*}{ S.Ed } & \multirow{2}{*}{ C.D } \\
\hline & & Airtight container & HDPE & PP & & & & \\
\hline \multirow{5}{*}{$\begin{array}{c}\text { Overall } \\
\text { acceptability }\end{array}$} & 0 & $9.00 \pm 0.00$ & $9.00 \pm 0.00$ & $9.00 \pm 0.00$ & $9.00^{\mathrm{a}} \pm 0.00$ & \multirow{5}{*}{\begin{tabular}{|} 
For factor packaging $(\mathrm{P})$ \\
$92.23 * * *$ \\
For factor period $(\mathrm{D})$ \\
$1817.77 * * *$ \\
For factor interaction $(\mathrm{P} \times$ \\
D) $7.327 * * *$
\end{tabular}} & \multirow{2}{*}{0.01} & \multirow{2}{*}{0.32} \\
\hline & 7 & $8.70 \pm 0.05$ & $8.60 \pm 0.10$ & $8.50 \pm 0.10$ & $8.64^{\mathrm{b}} \pm 0.10$ & & & \\
\hline & 14 & $8.60 \pm 0.00$ & $8.40 \pm 0.02$ & $8.30 \pm 0.02$ & $8.46^{c} \pm 0.20$ & & & \\
\hline & 21 & $8.00 \pm 0.10$ & $7.80 \pm 0.02$ & $7.60 \pm 0.02$ & $7.81^{\mathrm{d}} \pm 0.20$ & & 0.02 & 0.04 \\
\hline & 28 & $7.40 \pm 0.10$ & $7.20 \pm 0.02$ & $7.10 \pm 0.09$ & $7.28^{\mathrm{e}} \pm 0.15$ & & 0.03 & 0.07 \\
\hline $\begin{array}{c}\text { Packaging material } \\
\text { Mean } \pm \text { SD }\end{array}$ & $\begin{array}{c}\text { Overall } \\
\text { acceptability }\end{array}$ & $8.36^{\mathrm{a}} \pm 0.60$ & $8.23^{\mathrm{b}} \pm 0.70$ & $8.12^{\mathrm{c}} \pm 0.75$ & & & & \\
\hline
\end{tabular}

Packaging material means and period of evaluation means covered by different letters are significantly different at $P<0.05 * * *$ signifies significant at $P<0.05$

Table 4: Impact of period and packaging materials in terms of moisture content of Treatment $\mathrm{T}$ kept across storage

\begin{tabular}{|c|c|c|c|c|c|c|c|c|}
\hline \multirow{2}{*}{ Parameter } & \multirow{2}{*}{$\begin{array}{c}\text { Period of } \\
\text { evaluation (Days) }\end{array}$} & \multicolumn{3}{|c|}{ Packaging materials (mean \pm SD) } & \multirow[t]{2}{*}{$\begin{array}{c}\text { Period of evaluation } \\
\text { (Days) mean } \pm \text { SD }\end{array}$} & \multirow[t]{2}{*}{ F value } & \multirow{2}{*}{ S.Ed } & \multirow{2}{*}{$\left.\begin{array}{l}\text { C.D } \\
(\mathbf{0 . 0 5})\end{array}\right)$} \\
\hline & & Airtight container & HDPE & PP & & & & \\
\hline \multirow{5}{*}{ Moisture } & 0 & $6.50 \pm 0.10$ & $6.50 \pm 0.03$ & $6.50 \pm 0.02$ & $6.50^{\mathrm{d}} \pm 0.00$ & \multirow{5}{*}{$\begin{array}{l}\text { For factor packaging } \\
(\mathrm{P}) 21.591 * * * \\
\text { For factor period }(\mathrm{D}) \\
203.173 * * * \\
\text { For factor interaction } \\
(\mathrm{P} \times \mathrm{D}) 2.896 * * *\end{array}$} & \multirow{2}{*}{0.04} & \multirow{2}{*}{0.08} \\
\hline & 7 & $6.80 \pm 0.01$ & $6.90 \pm 0.05$ & $7.00 \pm 0.01$ & $6.90^{\mathrm{d}} \pm 0.10$ & & & \\
\hline & 14 & $7.00 \pm 0.02$ & $7.02 \pm 0.02$ & $7.04 \pm 0.06$ & $7.04^{c} \pm 0.02$ & & 005 & \\
\hline & 21 & $7.38 \pm 0.04$ & $7.49 \pm 0.07$ & $7.59 \pm 0.07$ & $7.48^{\mathrm{b}} \pm 0.10$ & & 0.00 & \\
\hline & 28 & $7.40 \pm 0.10$ & $7.54 \pm 0.02$ & $7.90 \pm 0.09$ & $7.61^{\mathrm{a}} \pm 0.20$ & & 0.02 & 0.04 \\
\hline $\begin{array}{c}\text { Packaging material } \\
\text { Mean } \pm \text { SD }\end{array}$ & Moisture & $7.01^{c} \pm 0.30$ & $7.09^{\mathrm{b}} \pm 0.40$ & $7.20^{\mathrm{a}} \pm 0.50$ & & & & \\
\hline
\end{tabular}

Packaging material means and period of evaluation means covered by different letters are significantly different at $P<0.05 * * *$ signifies significant at $P<0.05$

Table 5: Impact of period and packaging materials in terms of free fatty acid content of Treatment $\mathrm{T}$ kept across storage

\begin{tabular}{|c|c|c|c|c|c|c|c|c|}
\hline \multirow{2}{*}{ Parameter } & \multirow{2}{*}{$\begin{array}{c}\text { Period of } \\
\text { evaluation (Days) }\end{array}$} & \multicolumn{3}{|c|}{ Packaging materials (mean \pm SD) } & \multirow[t]{2}{*}{$\begin{array}{c}\text { Period of evaluation } \\
\text { (Days) mean } \pm \text { SD }\end{array}$} & \multirow[t]{2}{*}{ F value } & \multirow{2}{*}{ S.Ed } & \multirow{2}{*}{ C.D } \\
\hline & & Airtight container & HDPE & PP & & & & \\
\hline \multirow{5}{*}{ Free fatty acid } & 0 & $0.100 \pm 0.00$ & $0.100 \pm 0.00$ & $0.100 \pm 0.00$ & $0.100^{\mathrm{d}} \pm 0.0$ & \multirow{5}{*}{$\begin{array}{c}\text { For factor packaging } \\
(\mathrm{P}) 15.167 * * * \\
\text { For factor period (D) } \\
90.583 * * * \\
\text { For factor interaction } \\
\mathrm{P} \times \mathrm{D} 4.333 * * *\end{array}$} & \multirow{2}{*}{$\begin{array}{ll}\mathrm{g} & 0.42 \\
\end{array}$} & \multirow{2}{*}{0.84} \\
\hline & 7 & $0.090 \pm 0.01$ & $0.100 \pm 0.00$ & $0.100 \pm 0.01$ & $0.100^{\mathrm{d}} \pm 0.1$ & & & \\
\hline & 14 & $0.100 \pm 0.01$ & $0.110 \pm 0.00$ & $0.110 \pm 0.00$ & $0.108^{c} \pm 0.02$ & & 0.54 & 109 \\
\hline & 21 & $0.110 \pm 0.00$ & $0.110 \pm 0.01$ & $0.120 \pm 0.01$ & $0.110^{\mathrm{b}} \pm 0.1$ & & & \\
\hline & 28 & $0.120 \pm 0.00$ & $0.130 \pm 0.01$ & $0.140 \pm 0.00$ & $0.120^{\mathrm{a}} \pm 0.2$ & & 0.94 & 1.80 \\
\hline $\begin{array}{l}\text { Packaging material } \\
\text { Mean } \pm \text { SD }\end{array}$ & Free fatty acid & $0.106^{\mathrm{c}} \pm 0.3$ & $0.110^{\mathrm{b}} \pm 0.4$ & $0.114^{\mathrm{a}} \pm 0.5$ & & & & \\
\hline
\end{tabular}

Packaging material means and period of evaluation means covered by different letters are significantly different at $P<0.05 * * *$ signifies significant at $P<0.05$

Table 6: Impact of period and packaging materials in terms of peroxide value of Treatment $\mathrm{T}$ kept across storage

\begin{tabular}{|c|c|c|c|c|c|c|c|c|}
\hline \multirow{2}{*}{ Parameter } & \multirow{2}{*}{$\begin{array}{c}\text { Period of } \\
\text { evaluation (Days) }\end{array}$} & \multicolumn{3}{|c|}{ Packaging materials (mean \pm SD) } & \multirow[t]{2}{*}{$\begin{array}{c}\text { Period of evaluation } \\
\text { (Days) mean } \pm \text { SD }\end{array}$} & \multirow[t]{2}{*}{ F value } & \multirow{2}{*}{ S.Ed } & \multirow{2}{*}{$\begin{array}{c}\text { C.D } \\
(\mathbf{0 . 0 5})\end{array}$} \\
\hline & & \begin{tabular}{|l|} 
Airtight container \\
\end{tabular} & HDPE & $\mathbf{P P}$ & & & & \\
\hline \multirow{5}{*}{ Peroxide value } & 0 & $3.390 \pm 0.01$ & $3.400 \pm 0.00$ & $3.400 \pm 0.00$ & $3.398^{\mathrm{d}} \pm 0.00$ & \multirow{5}{*}{$\begin{array}{c}\text { For factor packaging } \\
(\mathrm{P}) 21.800 * * * \\
\text { For factor period }(\mathrm{D}) \\
119.300^{* * *} \\
\text { For factor interaction } \\
(\mathrm{P} \times \mathrm{D}) 3.050 * * *\end{array}$} & \multirow{2}{*}{0.38} & \multirow{2}{*}{0.77} \\
\hline & 7 & $3.400 \pm 0.00$ & $3.400 \pm 0.00$ & $3.400 \pm 0.00$ & $3.400^{\mathrm{d}} \pm 0.00$ & & & \\
\hline & 14 & $3.400 \pm 0.00$ & $3.410 \pm 0.01$ & $3.410 \pm 0.01$ & $3.405^{\mathrm{c}} \pm 0.01$ & & 049 & \\
\hline & 21 & $3.410 \pm 0.01$ & $3.420 \pm 0.00$ & $3.420 \pm 0.01$ & $3.415^{\mathrm{b}} \pm 0.01$ & & 0.49 & 1.00 \\
\hline & 28 & $3.420 \pm 0.00$ & $3.430 \pm 0.02$ & $3.440 \pm 0.00$ & $3.427^{\mathrm{a}} \pm 0.01$ & & 0.85 & 1.70 \\
\hline $\begin{array}{l}\text { Packaging material } \\
\text { Mean } \pm \text { SD }\end{array}$ & Peroxide value & $3.405^{\mathrm{c}} \pm 0.01$ & $3.410^{\mathrm{b}} \pm 0.01$ & $3.413^{\mathrm{a}} \pm 0.00$ & & & & \\
\hline
\end{tabular}

Packaging material means and period of evaluation means covered by different letters are significantly different at $P<0.05^{* * *}$ signifies significant at $P<0.05$

\subsection{Moisture content across storage}

It is evident from Table 4 that Treatment $\mathrm{T}$ stored in different packaging materials have significant affect on changes in moisture content during storage. There was significant increase $(21.591 * * *)$ in moisture content across storage period. Mean moisture content of biscuit in airtight container was 7.01, in HDPE it was 7.09 and in PP it was 7.20. Highest moisture content was in PP followed by HDPE and then airtight container. Biscuit sample was also affected by factor period (203.173***). Moisture content increased as days increased. The interaction between factor packaging $(\mathrm{P})$ and period (D) was $\left(2.896^{* * *}\right)$. From factor period it can be observed that moisture content increased as days increased. On 28 days it was highest i.e. 7.61 per cent. The DMRT performed for packaging material indicates that the change in moisture content is comparatively low in airtight container, 
followed by HDPE and then PP. This may be due to structural difference, composition and thickness of three materials. The water vapour transition rate of three packaging materials differs which resulted in variation of moisture content of studied product. Khatoniar (2015) ${ }^{[9]}$, reported that moisture content of salty biscuit gradually increased as days increased, maximum increment of moisture was observed in PP pouches, followed by HDPE pouches then airtight container. Seevaratnam et al. (2012) ${ }^{[15]}$ reported that moisture content of Alternanthera sessilis and Amaranthas polygonoides dried green leafy vegetables samples packed in different packaging materials increased gradually with increase in storage period. The rate of increase in moisture was low in samples packed in HDPE followed by PP. Singh and Sagar (2010) ${ }^{[14]}$ studied quality characteristics of dehydrated leafy vegetables influenced by packaging materials. The results revealed that moisture retention was more in PP pouches (150 gauge) as compared to HDPE films (200 gauge). This might be due to high porosity of PP pouches than HDPE pouches.

\subsection{Free fatty acid content across storage}

It is evident from the Table 5 that treatment $\mathrm{T}$ stored in different packaging materials have significant affect on changes in free fatty acid content during storage. There was significant increase in free fatty acid content across storage. Mean free fatty acid content of biscuit in airtight container was 0.106 per cent, in HDPE it was 0.110 per cent and in PP it was 0.114 per cent. Highest free fatty acid content was in PP followed by HDPE and then airtight container. Biscuit sample was also affected by factor period (90.583***). Free fatty acid content increased as days increased. From factor period it can be observed that free fatty acid content increased as days increased. On 28 days it was found to be highest $(0.120 \%)$. Although increment is there, but this increment did not cause any rancid Odour or off flavor as indicated. All the values were under permissible limit. However, free fatty acid value of present study are within the standard specified by FSSAI, 2018 (i.e. $0.25 \%$ FFA).

Similar result was reported by Mishra et al. (2015) ${ }^{[11]}$ where little changes in free fatty acid content with increasing storage period was observed in fortified Bengal gram sattu. In another study conducted by Mridula et al. (2009) ${ }^{[12]}$ reported that free fatty acid content increased mainly from degradation products of hydro peroxide which is directly related with relative humidity and moisture content of the products.

\subsection{Peroxide value across storage}

Peroxide value is an indicator of rancidity development during storage. The mean peroxide value of prepared biscuit is presented in Table 6 . The mean peroxide value increases very minutely from 0 day onwards, i.e. $3.398 \mathrm{mEq} / \mathrm{kg}$, in 7 days $3.400 \mathrm{mEq} / \mathrm{kg}$ oil, in 14 days $3.405 \mathrm{mEq} / \mathrm{kg}$ oil, in 21 days $3.415 \mathrm{mEq} / \mathrm{kg}$ oil and in 28 days $3.427 \mathrm{mEq} / \mathrm{kg}$ oil over a storage period of 28 days. Mean peroxide value of biscuit sample kept in different packaging materials increased as days increased. Mean peroxide value is highest in PP pouch i.e. $3.413 \mathrm{mEq} / \mathrm{kg}$ oil followed by HDPE $3.410 \mathrm{mEq} / \mathrm{kg}$ oil and airtight container as $3.405 \mathrm{mEq} / \mathrm{kg}$ oil. The increase in peroxide value is probably due to peroxidation of double bonds in unsaturated fatty acid which respectively breakdown in order to produce secondary oxidation products that may indicate rancidity (Ihekoronye and Ngoddy, 1985) ${ }^{[8]}$. Although there is increase in peroxide value as days increased but values were under permissible limit. However, peroxide value of present study are within the standard specified by
FSSAI, 2018 (i.e. $10 \mathrm{mEq} / \mathrm{kg}$ oil). Sujitha and Devi, (2014) [16] also reported that there was no rancidity in formulated breakfast biscuits up to 60 days.

\section{Conclusion}

Thus, it can be concluded from the study that, gluten free biscuit which was prepared can be stored in ambient temperature in different packaging materials like High Density Polyethylene (HDPE), Polypropylene (PP) and airtight container but airtight container was found best in every aspect like moisture content, free fatty acid and peroxide value of biscuits in 28 days. As the prepared biscuit were found low in free fatty acid and peroxide value, so it can be successfully consumed upto 28 days if kept in good packaging condition. Therefore, it will be a very good value added product with nutritional intervention as well as good storage stability.

\section{References}

1. AOAC. Official methods of analysis. Association of Official Analytical Chemists $12^{\text {th }}$ edition, Washington, D.C, 1975.

2. AOAC. Approved methods of Association of Official Analytical Chemists $14^{\text {th }}$ edition, Washington, D.C, 2010.

3. Berwal RK, Khanna N, Berwal R. Storage quality of chicken meat mince incorporated cookies under aerobic packaging at ambient temperature. J Meat Sci. Technol. 2013; 1(1):28-34.

4. Cox HE, Pearson D. The chemical analysis of foods. Chemical publishing co. Inc. Newyork, 1962, 420.

5. Food Safety and Standards Authority of India report (FSSAI), 2018.

6. Gomes KA, Gomes AA. Statistical procedures for agricultural research Second edition, John Wiley and Sons A Wiley- Interscience Publication, 1984.

7. Hopman EG, Le CS, Blomberg BM, Mearin ML. Nutritional management of the gluten-free diet in young people with $\mathrm{CD}$ in the Netherlands. J Pediatr Gastroenterol Nutr. 2006; 43:102-108.

8. Ihekoronye A, Ngoddy P. Integrated food Science and Technology in the Tropics, MacMillan Education Limited, 1985, 338-339.

9. Khatoniar S. Development of Products from Selected Green Leafy Vegetables for Iron and Calcium Security. M.sc thesis. Dept. of Food Science and Nutrition, College of Community Sc. Assam Agricultural University, Jorhat, 2015.

10. Masoodi L, Aeri V, Bashir K. Fortification of biscuit with flaxseed: Biscuit production and quality evaluation. $\mathrm{J}$ of environmental science, toxicology and food technology. 2012; 1(5):2319-2402.

11. Mishra A, Jha P. Development of gluten free biscuits utilizing fruits and starchy vegetable powders. J Food Sci Technol. 2015; 52(7):4423-4431.

12. Mridula D, Jain R, Singh KK. Quality, acceptability and shelf life of micronutrient fortified Indian traditional Sattu. J Agric. Eng. 2009; 46(2):26-32.

13. Pasha I, Butt MS, Anjum FM, Shahzadi N. Effect of dietetic sweeteners on the quality of cookies. Int. J Agric. Biol. 2002; 4:245-248.

14. Singh U, Sagar VR. Quality characteristics of dehydrated leafy vegetables influenced by packaging materials and storage temperature. J Sci. Indust. Res. 2010; 69:785789. 
15. Seevaratnam V, Banumathi $P$, Premalatha MR, Sundaram SP, Arumugam T. Effect of Packaging Materials on Retention of Quality Characteristics of Selected Dehydrated Green Leafy Vegetables during Storage. World J Dairy Fd. Sci. 2012; 7(2):190-194.

16. Sujitha R, Devi AT. Physicochemical and sensory characteristics of value added Break fast biscuits. International journal of advanced research. 2014; 2(3):556-563.

17. Surekha N, Naik RS, Mythri S, Devi R. Barnyard Millet (Echinochloa frumentacea Link) Cookies: Development, Value Addition, Consumer Acceptability, Nutritional and Shelf life Evaluation. J Environ. Sci. Toxicol. Fd. Technol. 2013; 7(3):01-10. 